\title{
SEISMOTECTONIC HAZARDS ASSESSMENT IN SOUTHWESTERN SINAI AREA USING REMOTE SENSING AND GIS
}

\author{
Ali E. Omar ${ }^{* 1}$, M.O. Arnous ${ }^{2}$, M.A. El-Ghawaby ${ }^{2}$, \\ A.S. Alshami ${ }^{1}$ and M.A. El Zalaky ${ }^{1}$ \\ 1. Dept. Geology and Remote Sensing, Authority of Nuclear Materials, Egypt \\ 2. Dept. Geology, Fac. Sci., Suez Canal Univ., Egypt
}

\begin{abstract}
Major national development projects have been accomplished in Egypt, particularly around the Gulf of Suez - Sinai region. These include construction of national industrial projects, roads, ports, power station, mineral exploration, beach and village's tourist construction. The aim of this study is to assess and map the seismic activity at the southwestern section of Sinai, Egypt. In the present work, remote sensing and Geographic Information System (GIS) techniques are applied using satellite images, topographical, geological and other ancillary geological data. GIS data integration and analysis indicated that the area is threatened to environmental seismotectonic hazard. These depend on the geological, local seismic activity and the structure analyses of data that are extracted from remote sensing and geo-references data. The structural lineaments analysis data extracted from enhanced Landsat 8 (OLI) image showed that major trends of seismic activity is strongly reduced along the segment fault system of the Gulf of Suez and Gulf of Aqaba. The main characteristics of the seismtectonics of the study area are investigated based on the geological data and seismic activity using the recently recorded data by the Egyptian National Seismic Network (ENSN), in the period between 1904-2005. Accordingly, the assessment of the seismic activity hazard was taken into consideration through identification of the sources of events. Almost all of these events $(91.75 \%)$ were micro earthquakes and about $8.25 \%$ had small measurable magnitudes $(4.4>$ ML $>=3.0$ ). The statistical analyses and geospatial mapping are carried out to extracted structural lineaments and seismic activities. The integrated map of the seismotectonic is constructed and showing the distribution sites of the hazards anomalies. The distribution of seismic activity pattern and previously mentioned data analysis for the study area clearly showed the urgent need for an assessment and rehabilitation program to mitigate geo-hazard environmental in existing structures.
\end{abstract}

Key word: Seismotectonic, hazards assessment, southwestern Sinai Area, using remote sensing, GIS.

\section{INTRODUCTION}

Sustainable development of the Gulf of Suez has accelerated rapidly in the last three decades for relieving population pressure in the narrow Nile Valley and Delta (Arnous et al., 2011). Today the southwestern part of Gulf of Suez-Sinai region is considered as the most important area particularly at Abu Zeneima. To obtain a usable development plan for a desert and rocky area requires an accurate and precise geo-environmental assessment of the area as a starting point. There are two

* Corresponding author: Tel.: +201009892307

E-mail address: aliomarnma@gmal.com 
components to a geo-environmental assessment: an area resources inventory and a hazards mitigation determination (Arnous, 2004; Arnous et al., 2011). To achieve sustainable development of an area, a comprehensive assessment of natural hazard risks should be conducted. Risk assessment is required as a step towards the adoption of adequate and successful disaster reduction policies and measures. Risk assessment encompasses the systematic use of available information to determine the likelihood of certain events occurring and the magnitude of their possible consequences.

As a process, it is generally agreed (Smith, 2001) that it includes: identifying the nature, location, intensity and probability of a threat; determining the existence and degree of vulnerabilities and exposure to those threats; identifying the capacities and resources available to address or manage threats; and determining acceptable levels of risk.

Both hazard and vulnerability capacity assessments utilize formal procedures that include the collection of primary data, monitoring of hazard and vulnerability factors, data processing, mapping and social survey techniques. One of the major natural hazards in the study area is the seismic activity represent the major natural hazards, resulting in the loss of life and economic losses due to the damage of buildings, industrial projects and businesses.

For the people who live in such areas risk management decisions need to be taken. Examples of such decisions include the level of the determination of a seismic design for whether or not the structural upgrading of buildings is appropriate based on some prediction of future geo-hazard events. However, existing technology does not enable the precise prediction of future events, and must use historic time series instead (Arnous et al., 2011). The integration of the historical seismic activities and tectonic with the structural measurements and other ancillary geological data by using remote sensing and geographic information system (GIS) tools that is clear and best to design and predict the geo-environmental hazards scenario model for future of any study area.

The aim of the present study is to assess and map the seismic activity at the southwestern section of Sinai, Egypt. To achieve the aim of this study remotely sensed data are used comprising image processing techniques, GIS, seismicity data, statistical analysis of photolineaments, followed by field investigation. A geological map and topographic map are used as a guide to delineate and extraction structural lineaments with Landsat-OLI and Aster GDEM space born data based on the remote sensing and GIS programs.

\section{Study Area}

The investigated area is located to the east of Abu Zeneima Town on the east coast of the Gulf of Suez, Southwestern part of Sinai, Egypt. This area is bounded between longitudes $33^{\circ} 05^{\prime}$ and $33^{\circ} 34^{\prime} \mathrm{E}$ and latitudes $28^{\circ} 52^{\prime}$ and $29^{\circ} 05^{\prime} \mathrm{N}$, and covers an area of about $3100 \mathrm{~km}^{2}$. (Fig. 1). It is covered by a sedimentary succession of Cambro-Ordovician, Lower Carboniferous, Cretaceous and Quaternary ages overlying the Proterozoic granitic rocks that have an age of $591 \pm 6 \mathrm{Ma}$ (Be'eri-Shlevin et al., 2009; Eyal et al., 2010) and comprising the northern part of the Arabo-Nubian crystalline massif. The Southern Sinai lies between the eastern and western flanks of the Red Sea Gulf rifts (Fig. 2) and it has been subjected to intensive faulting during the rift activities. There are two main fault structures, the first one runs along the contact between the sedimentary section and the basement complex, while the second one runs along the Gulf of Suez coast to the west. These two main faults are comparatively dissected by minor transversal faults and sometimes they branch into a series of small and roughly parallel step 


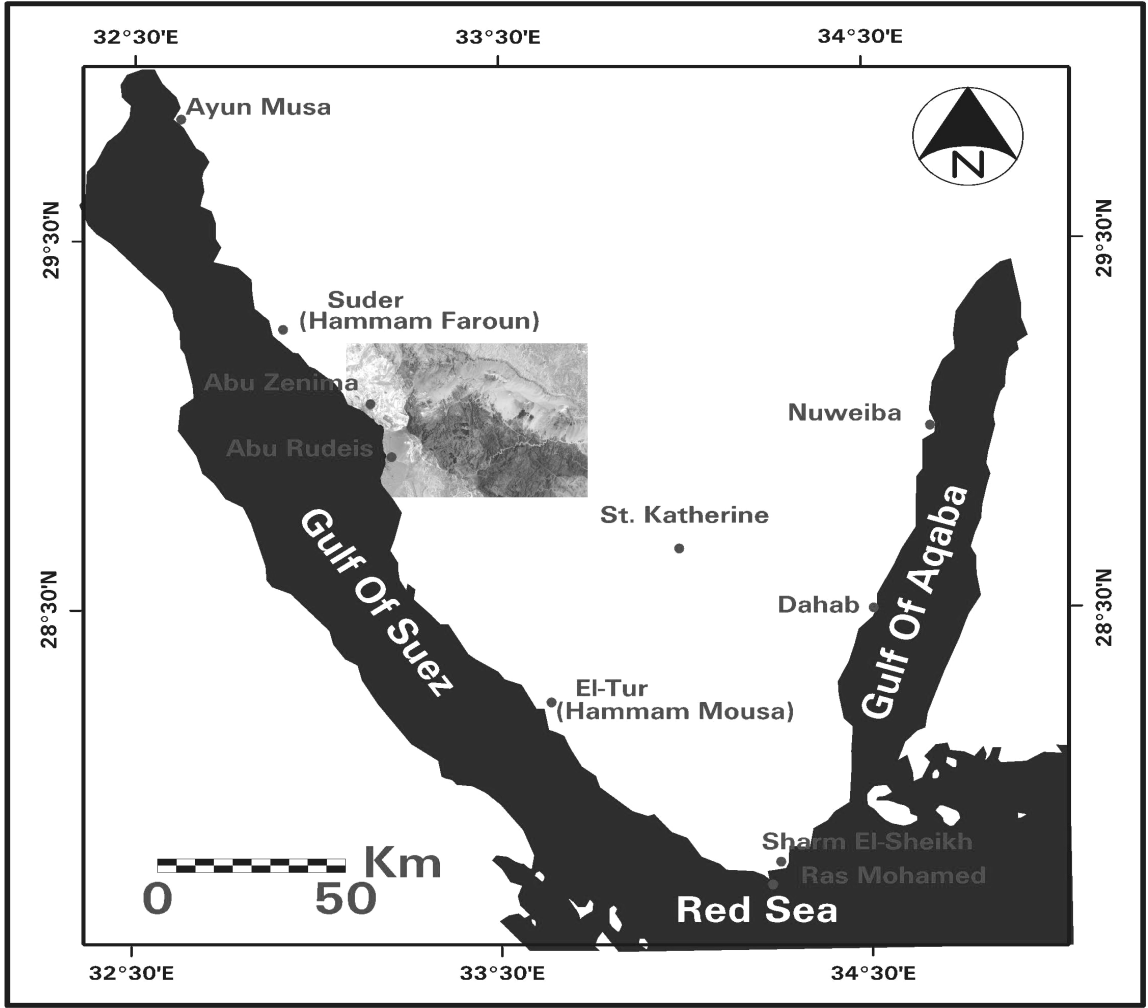

Fig. (1): Location map of the study area.

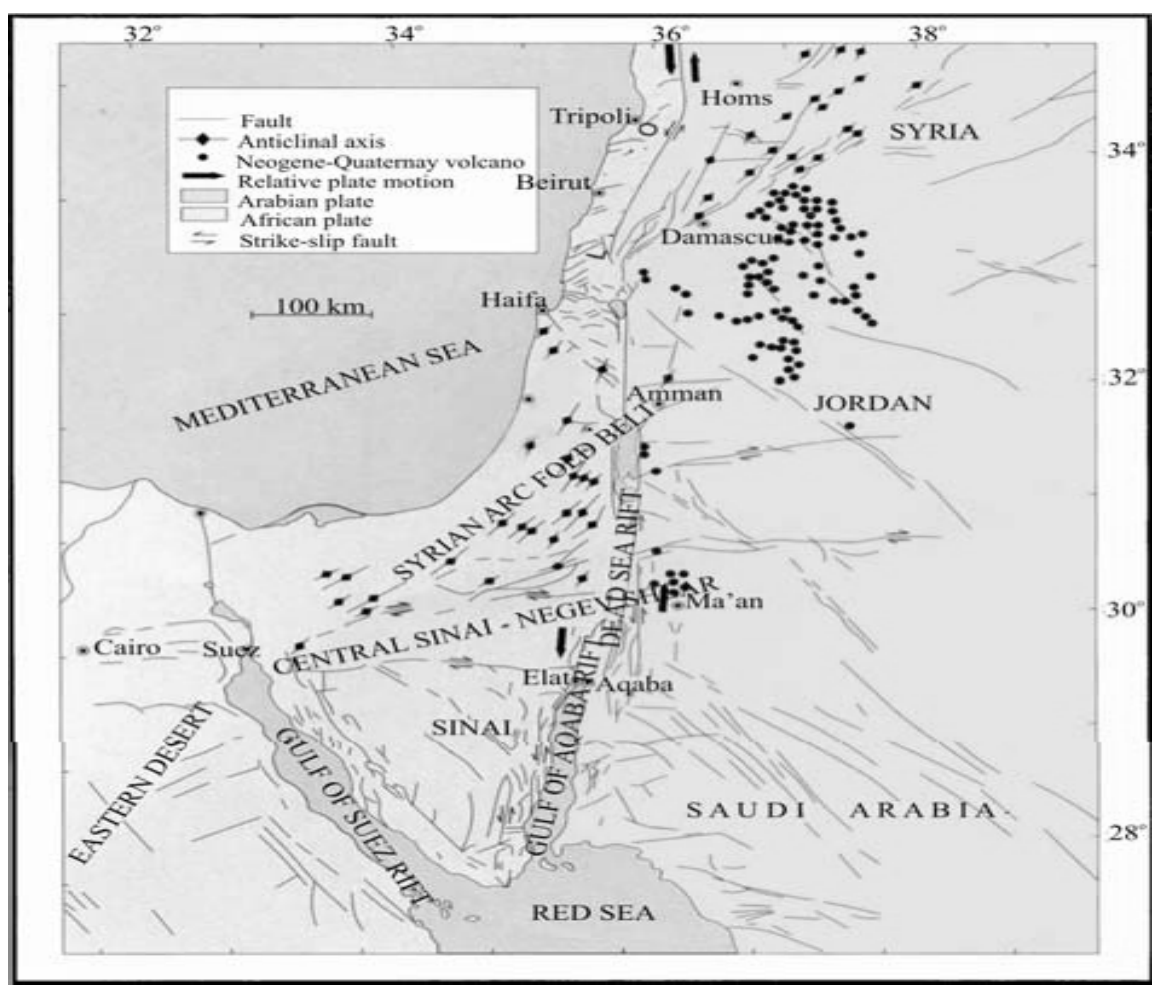

Fig. (2): Major tectonic boundaries of Sinai subplate (after Diabat, 2011). 
faults (Abdallah and Abu Khadra, 1976).

The Red Sea Basin Province originated as an Oligocene continental rift impacted by left-lateral wrenching. Rift location and borders are defined by crustal weaknesses created more than $500 \mathrm{Ma}$, including the late Proterozoic to early Paleozoic cratonization of the Arabian-Nubian shield, it's suturing to the African continent, and subsequent supercontinent breakup.

Those events resulted in the juxtaposition of structurally and compositionally different basement terranes. Said (1962) and ElGezery and Marzouk (1974) showed that the depth of the basement increases northwards towards the Mediterranean Sea. The Paleozoic rocks are characterized by continental clastic deposits. The marine episodes are minor in space and time. The Southwestern Sinai area forms topographically moderate mountain peaks such as Gabal (G.) Um Rinna, G. Hazbar and G. Nasib and is dissected by numerous valleys (wadis) such as W. Baba, W. El-Seih, W. Allouga, W. Nasieb, and W. Hamata. The major one (Wadi Baba) that forms the western boundary of the study area, originated through the joining of Wadi Nasieb with Wadi Seiht of the study area.

These wadis are mainly structurally controlled by the NW and NE fault trends. The study area is dominated by an arid climate of desertic conditions. It has low precipitation, high evaporation and temperature with a long hot summer and a short mild winter. In addition, it occasionally receives heavy rain storms every two or four years (El-Shamy, 1983), producing heavy flash floods. Many geological, structural, geochemical and geophysical studies have been carried out on the study area such as El-Kassas (1967),

Soliman (1975), Moustafa (1987), EI Shahat and Kora (1988), El Rakaiby and El Aassy (1989), El Sharkawi et al. (1990), Mansour (1994), Bishay (1994), Morsy et al. (1995), Botros (1995),
Ashami (1995 and 2003), Aita (1996), ElAgami (1996), Amer (1997), Abd ELMonem et al. (1997), Ammar et al. (1999), Afifi (2001), Abdelaziz (2000), El Aassy et al., (2003) Shata (2006), El Aassy et al. (2011), Khalifa and Arnous (2012), ElRayes and Arnous (2015) and El-Rayes $e t$ al. (2015).

\section{MATERIALS AND METHODS}

Seismotectonic activity hazards assessment methodology is used in this study to determine the nature and extend the risk, also, to minimize damage and to anticipate the future save development for the strategic projects. Several material and methods are used in the present study the seismotectonic hazards of the study area. Software such as ERDAS EMAGINE 9.2 and Arc GIS 10.2 are used. The materials used in this paper include collecting remote sensing data, georeferenced data, as well as tabular and ancillary data.

Remote sensing data analysis of multispectral Landsat satellite images such as Operational Landsat Imager (OLI) data that have 175 Path $/ 40$ Row with $(30 \times 30 \mathrm{~m})$ spatial resolution, dated 2013 covers the area of study and have number of bands (11 bands). These image was used to estimate extracted structural lineaments; the geotectonic setting of the study area. These data are geo-referenced to the UTM coordinate system, zone 36 North, based on topographic map.

Tabular and ancillary data including seismicity distribution over the study area during the period 1904-2005 have been obtained from the National Earthquake Information Centre (NEIS), the International Seismological Centre (ISC), and the Egyptian National Seismic Network (ENSN).

In the current study, the applied digital image enhancement techniques on Landsat (OLI) such as: spatial filtering convolution kernel and brightness inversion. Spatial 
filtering convolution kernel is the most important enhancement technique in the digital image processing used for recognition, interpretation and mapping of lineaments and structural linear features. It modifies pixel values based on the values of surrounding pixels.

It deals largely with spatial frequency, which is difference between the highest and lowest values of a continuous set of pixels (ERDAS, 1982-2001). It is defined as the number of change in brightness values per unit distance for any particular part of an image, or it is the rate of variations in the spatial domain (Gupta, 1991). In the present study, spatial filtering was performed using different convolution kernel on image. Among these convolutions kernels are highpass frequency $(5 \times 5)$ kernel size and sharpen filter 2 .

\section{Statistical Treatment of Lineaments}

Hardcastle (1995) suggested that three key characteristics, which can be used to rank areas potential to store and transmit large volume of fluid. These characteristics include the number of photolineament, the number of directional photolineament families, and the total length of photolineament factor.

Photolineament factor is a useful parameter in the investigation for probable mineral resources in fractured rock units. Also, it is very effective in areas where the rock units are relatively more fractured and therefore, capable of storing and transporting significant volumes of hydrothermal solutions.

The different processing steps of driving photolineament factor values (Arnous, 2000; El-Ghawaby et al., 2001; Arnous 2004), that well be portrayed as contour maps as follows:

1) Digitizing the major structural lineaments and then save them as a line layer using the ERDAS imagine. This coverage contains data such as length, numbers, directional families, longitude contains data such as length, numbers, directional families, longitude, and latitude at each counting cell node.

2) Creating square grid: photolineament are analyzed based on a square grid that contains values of the three parameters (length, numbers, and direction). Counting lineament should be accomplished using counting cell (Mostafa and Qari, 1995). To compute the optimal counting cell dimension; two variables are counted with varying cell dimensions; these are lineament frequency and lineament to cell intersection (Zakir et al., 1999). Consequently, the intersection point of the two variable lines defines the optimal cell dimension.

3) Counting of parameters: the total number, number of directional families and the total length of photolineament that occur within a definite cell, are calculated and their values are assigned to cells node.

4) Normalization of values: the values for each three parameters at each node are normalized by dividing it by the average values of those parameters in the study area. The normalized values of the total number, the number of directional families and the total length of photolineament are denoted as N, D and $\mathrm{L}$ respectively.

5) Weighting: each value is independently weighted by constants a, bn and c that are determined by the study's objectives, where:

$\mathrm{a}=$ weight value of the total number

bn=sum of weights of individual directions

$\mathrm{c}=$ weight value of the total length

6) Summation of the weighted values of the three parameters.

At each node the summation of the weighted values of the three parameters 
gives the photolineament factor $(\mathrm{F})$ as follows:

$$
\mathrm{F}=\left(\mathrm{a} \mathrm{N}+\mathrm{b}_{\mathrm{n}} \mathrm{D}+\mathrm{c} \mathrm{L}\right) / \text { area of counting cell }
$$

7)Contouring: photolineament factor values at each node are contoured and displayed as a contour map. The map exhibits areas that are most likely underlain by highly fractured rocks and capable of causes of seismo-tectonic activity. Therefore they are targets for further detailed field evaluations.

Intensity Distribution of the Earthquakes: The collected seismological data has been subjected to some treatments such as treatment for uniformity, through making use of the conversion relationships and the treatment of incompleteness through using the average pattern formula by (Al-Ibiary, 2000). In addition to such seismological, the available geological and geophysical information has been utilized to construct a seismo-tectonic model characterizing the area of concern. The average pattern was produced using the following formula, based on the observed maximum intensity values of particular events as well as on the proper evaluation of the existing isoseismal maps for the historical and recent earthquake epicenters:

$$
\mathrm{P}_{\mathrm{k}}=(10 / \mathrm{N}) \sum\left(\mathrm{I}_{\mathrm{k}}{ }^{\mathrm{i}} / \mathrm{I}^{\mathrm{i}, \max }\right)
$$

Where:

$\mathrm{N}$ is the number of observation, it indications of the seismic intensity at Kth location for ith earthquake, and Ii, max is the observed maximum intensity for the ith earthquake.

Geographical Information System (GIS) in combination with remote sensing and photogrammetry can be used to identify hazards. GIS is implemented and applied for integration the relevant information to identify the geohazards vulnerability in the study area. The present work also describes a system designed for the investigated area demonstrating the management structure of this system, which has been developed by using ERDAS imagine 9.2 software. The present work involves the establishment of a database in a digital format for the study area. Also, various GIS applications, including visualization, spatial query, integration, analysis and predictions have been carried out to produce maps of seismotectonic hazard and produce land use potentials map of the study area.

\section{RESULTS AND ANALYSIS}

Satellite remote sensing data joined with to Geographic Information Systems (GIS) offer excellent alternative to conventional mapping techniques in the monitoring and seismotectonic hazard mapping of the study area. One of the main goals of this study is to extract the major structural lineaments of the study area by applying the best enhancement techniques on Landsat 8 (OLI).

The term lineament is used to describe any linear topographic feature such as segments of drainage, ridge and escarpments (Hill, 1992). Although lineaments are surficial topographic features, they also reflect the subsurface structures namely, fractures that serve as a route for movement of fluids and gases. Lineaments analysis of the study area is carried out with the aid of enhancement different types of satellite images. Although a number of radiometric and spatial enhancements could be applied.

In the present study, for the purpose of lineament analysis spatial filtering was performed using different convolution kernels on images of the study area. Among these convolutions, kernels that give the best results are high-pass frequency $(5 \times 5)$ kernel size (Fig. 4) and sharpen filter 2. Therefore, the resulting image would be suitable for lineament mapping purposes and not suitable for lithological mapping. The other kind of image enhancement is brightness inversion (Fig. 5) which gives the best result for lineament mapping (Fig. 6). the extracted structural lineaments will be compared and integrated with the other geological ancillary data and then field verified in order to give complete picture on the structure setting of the area. 
SINAI Journal of Applied Sciences (ISSN: 2314-6079) Vol. (5) Is. (3), Dec. 2016

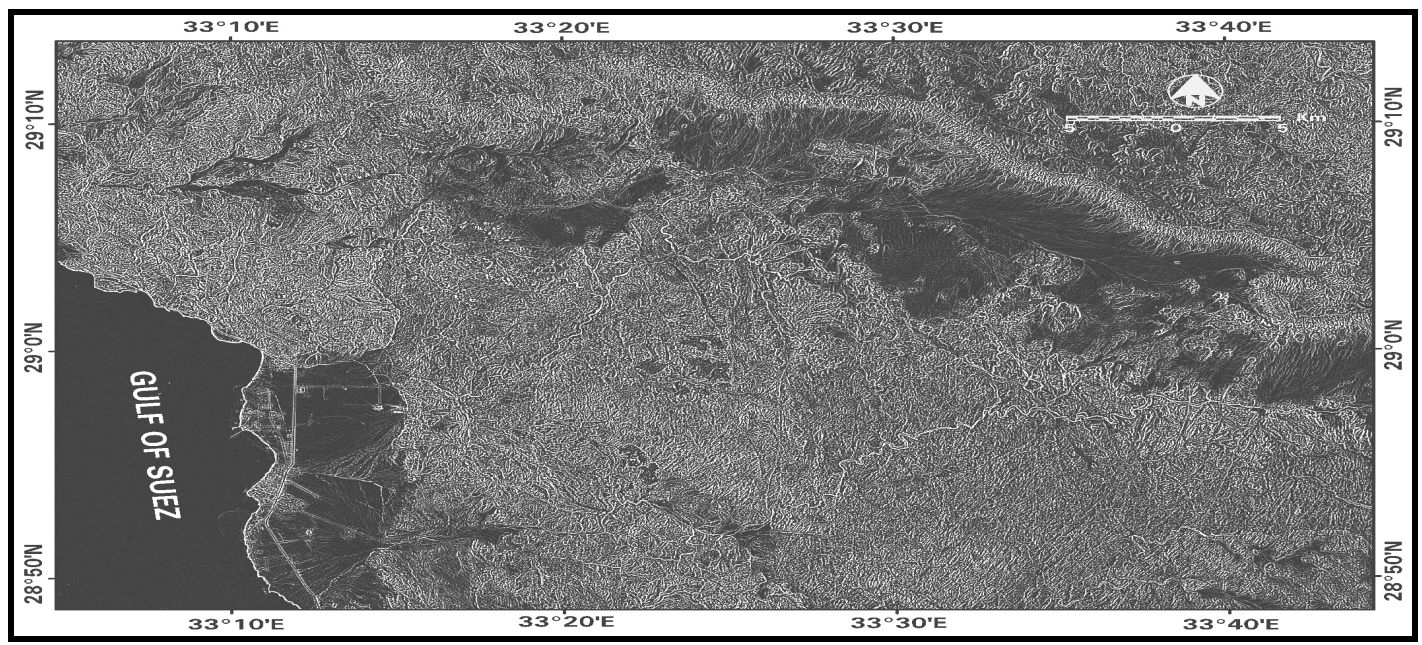

Fig. (3): Landsat 8-image enhanced by the high-pass filter $(5 \times 5)$ kernel size of the study area.

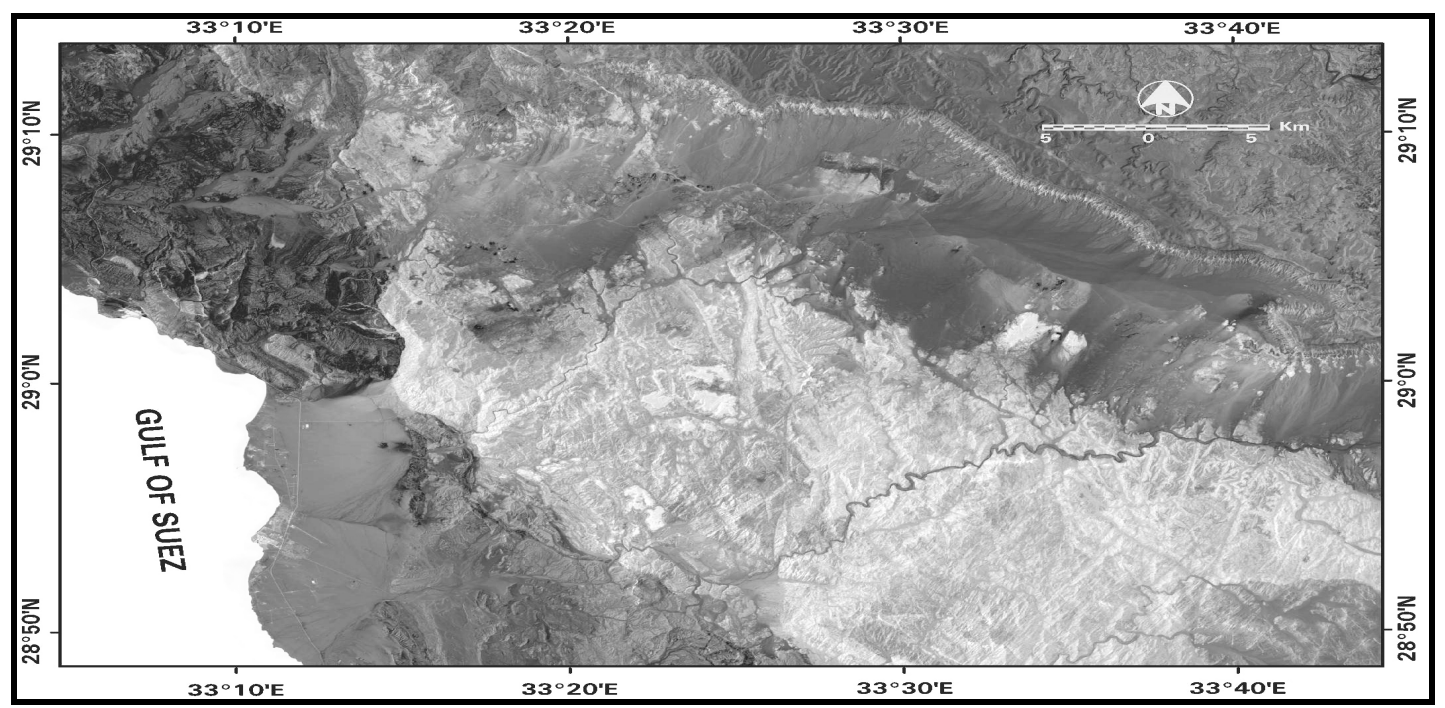

Fig.(4): Landsat 8-image enhanced by brightness inversion of the study area.

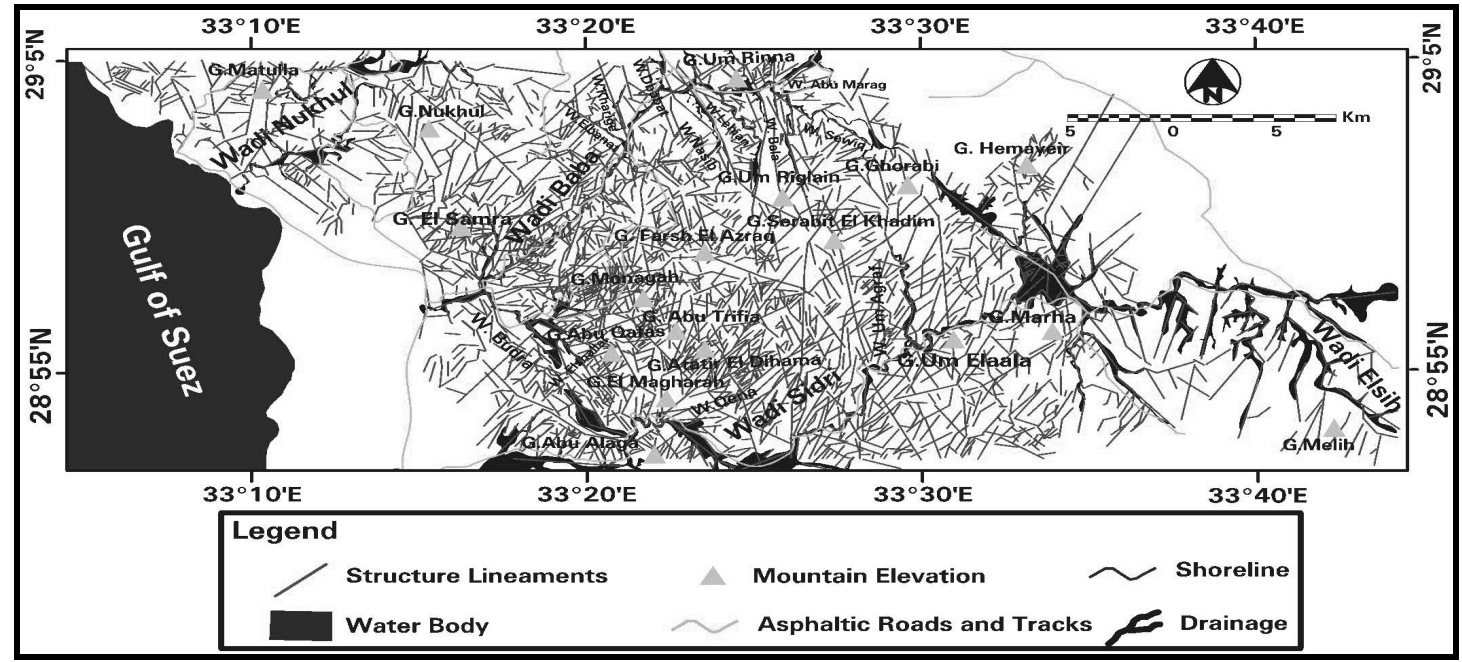

Fig. (5): Surface structural lineaments map of the study area, integrated from enhances Landsat 8 images. 


\section{Statistical Treatment Of Lineaments}

Each photolineament was identified on the images, by its two ends, and then digitized into a computer. Moreover, each photolineament is described by its length, azimuth, latitude and longitude of every two points. The photolineaments are analyzed based on square grid that contains values of the three parameters (length, numbers, and directional families) at each node in a database file. The optimal cell dimension for the grid database is used in counting the different lineament parameters where, the two counts are intersected at a value equal to 1.5 (Fig. 6), that means the optimal cell dimension is considered to be equal $1.5 \mathrm{~km}^{2}$ in order to construct the grid database coverage. Then the values for each different parameter at each grid node are normalized and weighted by constants.

According to the field investigation and previously published studies of structures, total number given weight value $(15 \%)$ because the total number of lineament is little effected on the earthquake activities and the total length is given weight value $(25 \%)$ because the total length of lineament is large effected on the earthquake activities.

The directional family parameters are treated independently and each direction is given a definite weight value (Fig. 7), based on its relation to the active faulting of the study area. Four directional families are recorded, they are, EW, NW, NE, and NS. Furthermore, the weighting values assigned to each direction are as follow: EW (15\%), NW (12.5\%), NE (12.5\%), NS (10\%), NNW (3\%), NNE (3\%), WNW (2\%), and ENE $(2 \%)$. Sum of weighted values of the three lineament parameters, length, number and directional families, can be considered as the photolineaments factor values that be displayed as a contour map. The map exhibits areas that are most likely underlain by highly fractured rocks, that be caused by seismo-tectonic activity (Fig. 8). Therefore, this map enables us do quantitative ranking and selection of anomalous of high seismotectonic activity in the study area.
The study area is subdivided into four anomalies categories, very high (risk area), high, moderate and low. It exhibits one essential very high anomaly that located between Wadi El Shallal and Wadi Abu Natash and locates at southeast Wadi Baba and nearing to Gabal El Monagah and Gabal Abu Qafas. In addition to the speculation of high anomalies around the one very high anomaly. The first high anomaly locates at Gabal Monagah, and near from Gabal Abu Qafas, Gabal Abu Trifia and Gabal Farsh El Azraq. Also it locates at Wadi Baba and Wadi El Budra.

The second high anomaly locates over Gabal Atatir Al Dehami, and near from Gabal Abu Trifia and locates northwest Wadi Sidri (Table 1). The moderate and low anomalies are found in the east and west of the study area. These anomalies striking to NW-SE direction related to the Gulf of Suez direction. In order to verify this anomalies, accurate satellite images enhancement and detail mapping for structural lineaments were carried out to select areas that may be indicates the structural style extensional active tectonic in the study area. By overlaying the photolineament factor anomalies map of the study area (Fig. 8), and analysis the intersection structural trends for each anomaly of tectonic framework of the study area (Table 1).

\section{Seismotectonics and Earthquake Intensity Activity Hazard Mapping}

The seismotectonic activity considered as natural hazards in the present study due to causes the public health risks. The recent seismic activity in the northern Egypt is attributed to three options, these are active dislocation fault zones (Maamon and Ibrahim 1978) and both fault and Oligocene basalt (Moussa, 1989). In addition to tectonic activity in the east Mediterranean and along the Red Sea zones (Kulhanek et al., 1992 a \& b). The major fault lines which are clearly reflected NE, NW, NS and EW directions, however, the NNW, NNE, WNW and ENE trends are the minor order. 
SINAI Journal of Applied Sciences (ISSN: 2314-6079) Vol. (5) Is. (3), Dec. 2016

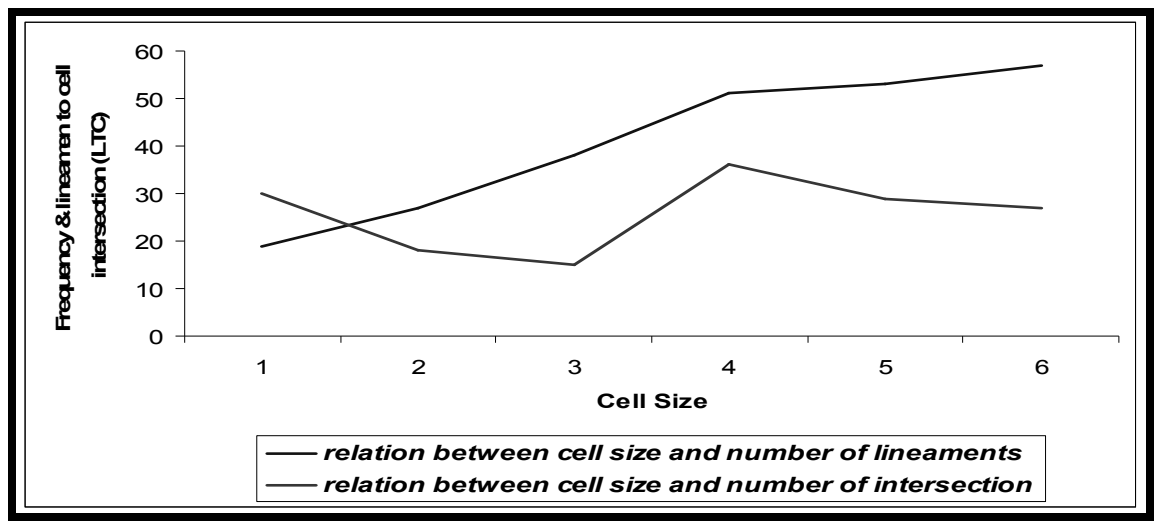

Fig. (6): The calculation of the optimal cell dimension used in counting photolineament parameters.

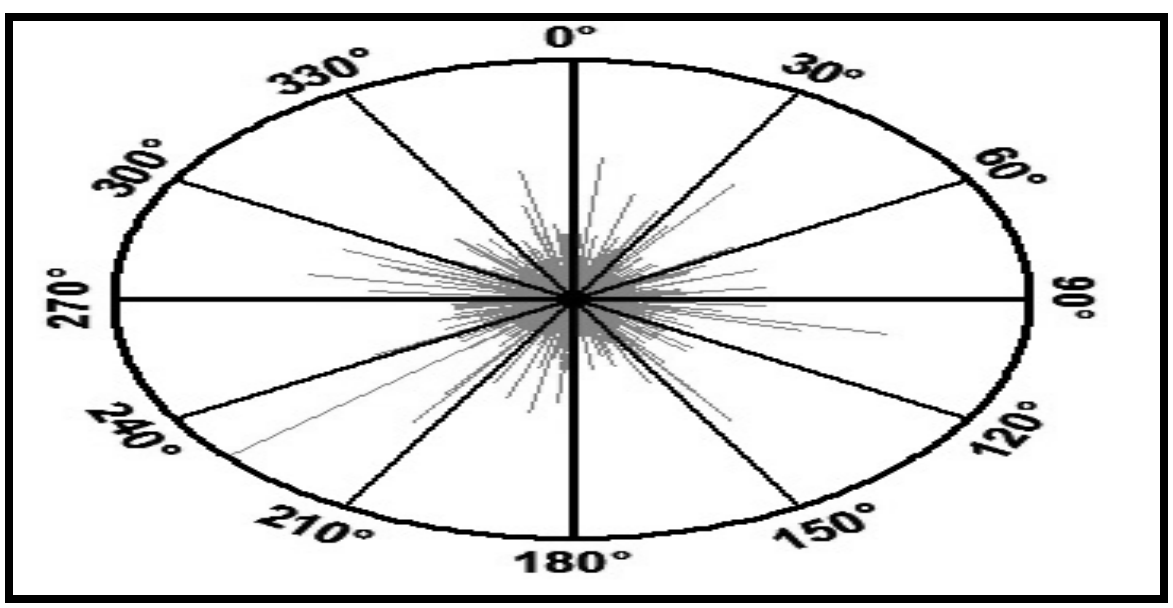

Fig. (7): Rose diagram of azimuth-frequency of major structural lineaments interpreted from satellite images and ancillary data in the study area.

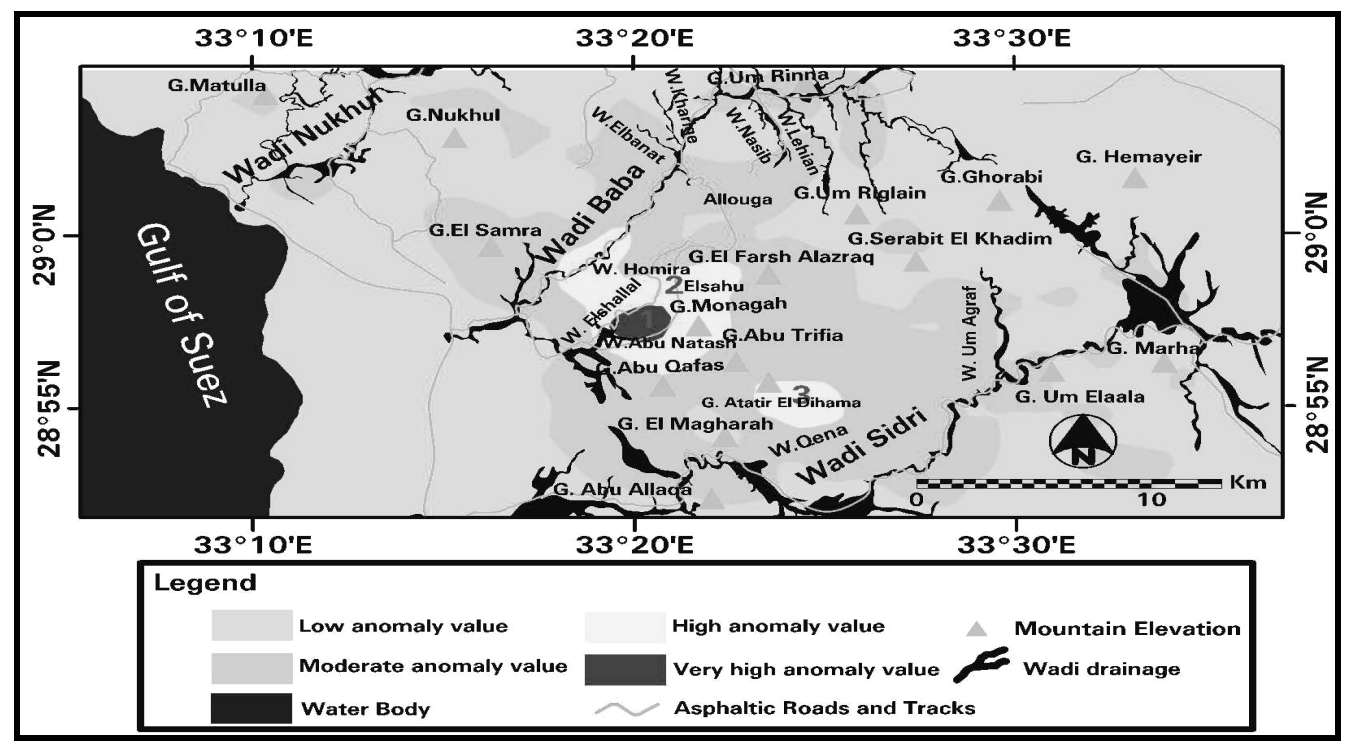

Fig. (8): Anomaly distribution map of influencing photolineament factor on seismotectonic of the study area. 
Table (1): Location of different very high and high photolineament anomalies.

\begin{tabular}{|c|c|}
\hline $\begin{array}{l}\text { Anomaly } \\
\text { No. }\end{array}$ & Location \\
\hline 1 & $\begin{array}{l}\text { Locates between Wadi Abu Natash and Wadi Elshalal and southeast Wadi Baba } \\
\text { and northwest of Gabal Monagah and Gabal Abu Qafas. }\end{array}$ \\
\hline 2 & $\begin{array}{l}\text { Locates at Gabal Monagah, and near from Gabal Abu Qafas, Gabal Abu Trifia and } \\
\text { Gabal Farsh El Azraq. Also locates at Wadi Baba and Wadi El Budra. }\end{array}$ \\
\hline 3 & $\begin{array}{c}\text { Locates over Gabal Atatir Al Dehami, nad near from Gabal Abu Trifia and locates } \\
\text { northwest Wadi Sidri. }\end{array}$ \\
\hline
\end{tabular}

The activity along these trends may indicate the termination of Gulf of Suez tectonics northward continuation into the Mediterranean. Therefore, a prominent EW zone of activity in the study area and the central Sinai seems to interrupt such possible continuation and affected mainly by a stress field with the principle stress axis acting almost horizontally and striking approximately in N-S direction related to the interaction between the African and European plates (Riad, et al., 1993). Seismology data from 1900 to 2001 has been collected and analyzed to conduct seismic hazard assessment at the study area (Fig.9). The seismic intensity map of the study area has been concluded by applying the equation proposed by Al-Ibiary (2000).

This equation has been discussed in the materials and methods in detail. The concluded seismic intensity map of the study area (Fig. 10) show nine locations, of high seismic risk probability. Three of them are very high and six are categorized as high anomalies. The locations, size, extensions and degrees of the magnitude anomalies listed in (Table 2). Generally, fractures represent another source of risk in the study area. In order to relevant the relation between earthquakes activities and structures of the study area, carrying out integration between the intensity hazards maps (Fig. 10) with the photolineament map (Fig. 5) by using Arc GIS program. The integrated map (Fig. 11) shows that there are close relations between photolineament and earthquake intensity anomalies.

\section{Conclusion}

The enhanced satellite images, seismicity, structural lineaments, geologic and topographic maps were used to classify and map the seismotectonic hazard at study area. The result of this integration approach showed that the seismic cluster and the photolineaments hazards areas can be identified and delineated. The concluded seismic intensity map of the study area show nine locations, of high seismic risk probability.

Three of them are very high and six are categorized as high anomalies. The locations, size, extensions and degrees of the magnitude anomalies were listed. This information is necessary to undertake a reliable evaluation of geo-hazard risk in the investigated area as well as the entire region southwestern Sinai. The distribution of seismic activity pattern and previously mentioned data analysis for the study area clearly showed the urgent need for an assessment and rehabilitation program to mitigate geohazard environmental in existing structures. Finally, it can be concluded that, this study is of considerable significance to decision makers, designers and planners regarding different construction projects in the area, such as power plants, dams, industrial centers, and pipelines. 
SINAI Journal of Applied Sciences (ISSN: 2314-6079) Vol. (5) Is. (3), Dec. 2016

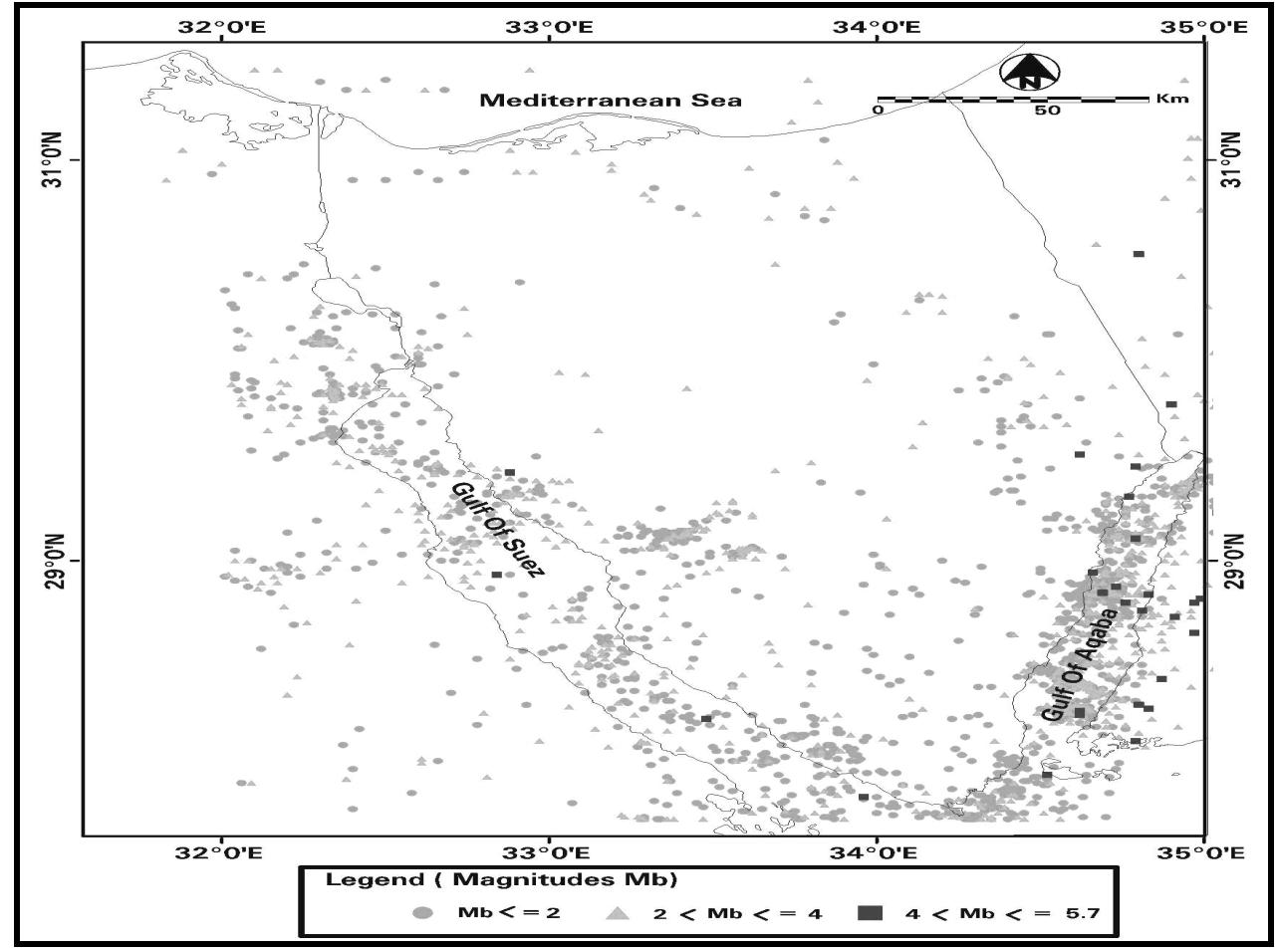

Fig. (9): Epicenters distribution of earthquake events recording during (1900-2001) for Egypt.

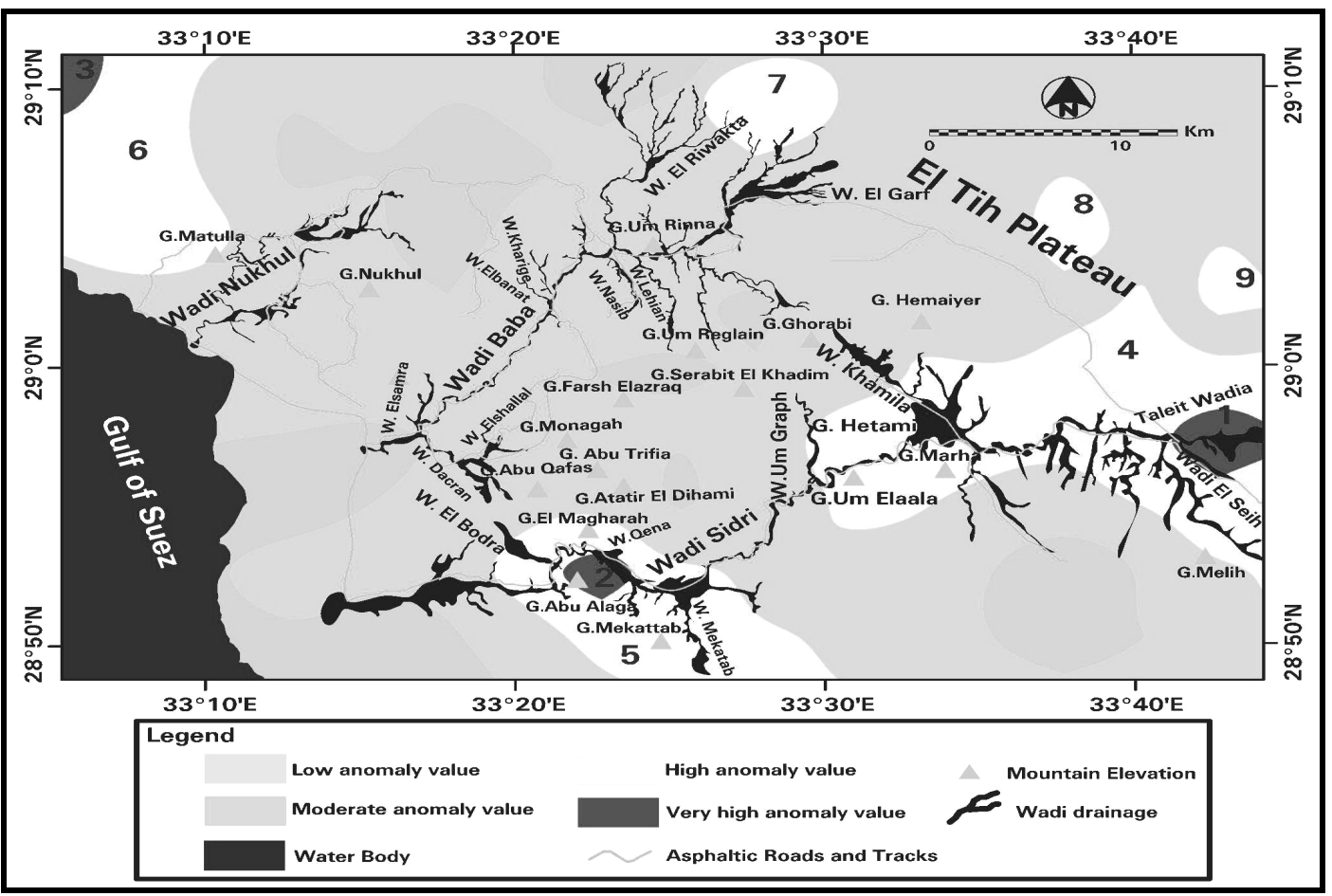

Fig. (10): The seismic intensity hazard anomalies map of the study area. 


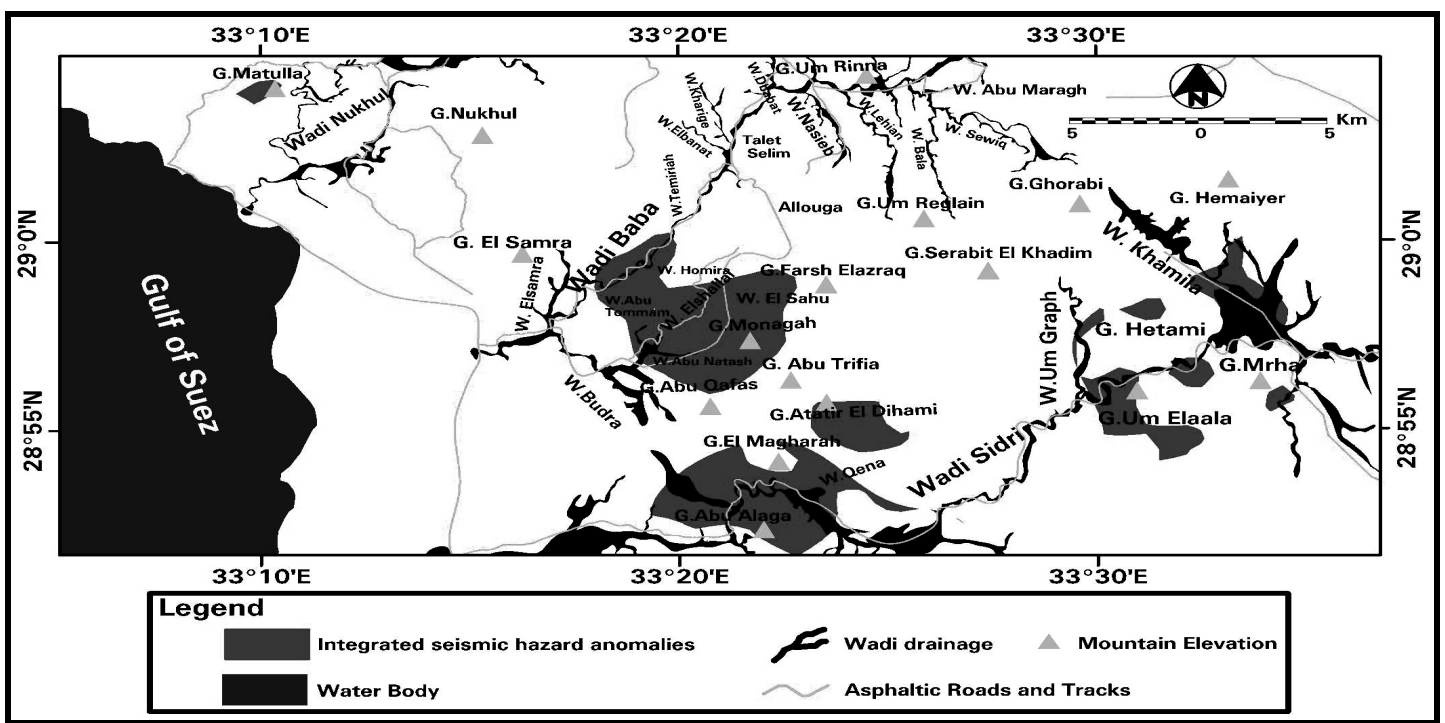

Fig. (11): Seismic hazards anomalies map of the study area, integrated from seismic intensity and photolineaments maps.

Table (2): Description of the seismic intensity hazard earthquake anomalies of the study area.

\begin{tabular}{|c|c|c|}
\hline $\begin{array}{l}\text { Anomaly } \\
\text { No. }\end{array}$ & $\begin{array}{c}\text { Hazard } \\
\text { degree }\end{array}$ & Location \& Extension \\
\hline 1 & Very High & $\begin{array}{l}\text { Distribution of seismic intensities observed in small extension of } \\
\text { anomaly located at end of Wadi Sidri at Wadi El Seih and Wadi Talet } \\
\text { Wadiea. }\end{array}$ \\
\hline 2 & Very High & $\begin{array}{l}\text { It represents a small extension of anomaly around Gabal Abu Alaqa } \\
\text { and near Gabal El Magharah, Wadi Qena and El Sheikh Soliman } \\
\text { localities. }\end{array}$ \\
\hline 3 & Very High & $\begin{array}{l}\text { It observed small anomaly located at Gabal Matulla and near Gulf of } \\
\text { Suez. }\end{array}$ \\
\hline 4 & High & $\begin{array}{l}\text { Seismic intensities are observed in extremely extended large anomaly } \\
\text { around anomaly (No.1). It located at Wadi Um Graph and Wadi } \\
\text { khamila extended to El Tih Plateau from Wadi Sidri. }\end{array}$ \\
\hline 5 & High & $\begin{array}{l}\text { It observed large extended anomaly around anomaly No. } 2 \text { in Wadi } \\
\text { Sidri. It located over Gabal El Magharah and Gabal Abu Alaqa and } \\
\text { extended to Wadi El Budra, Wadi Ghrar, Wadi Qena and Wadi } \\
\text { Mukatab. }\end{array}$ \\
\hline 6 & High & $\begin{array}{l}\text { It represented large extended anomaly around anomaly No. } 3 \text {. It } \\
\text { located at Gabal Matulla extended to northwest this Wadi. }\end{array}$ \\
\hline 7 & High & $\begin{array}{l}\text { It represented small extended anomaly at east Wadi Baba near Wadi } \\
\text { El Rewakta and Wadi El Garf at El Tih Plateau. }\end{array}$ \\
\hline 8 & High & $\begin{array}{l}\text { It represented small extended anomaly at southeast of Wadi Baba, } \\
\text { Wadi Sidri and El Tih Plateau. }\end{array}$ \\
\hline 9 & High & $\begin{array}{l}\text { It represented small extended anomaly Wadi Baba, Wadi Sidri and El } \\
\text { Tih Plateau. }\end{array}$ \\
\hline
\end{tabular}




\section{REFERENCES}

Abdallah, A.M. and Abu Khadra, A.M. (1976). Remark on the geomorphology of the Sinai Peninsula and its associated rock, Egypt. Geol. Surv., Egypt.

Abd El-Monem, A.; El-Aassy, I.E.; Hegab, O.; El-Fayomy, I. and El-Agami, N. (1997). Gibbsite uranium and copper mineralization, Um Bogma area, south western Sinai, Egypt. Sedimentol. Egypt, 5: 117-132.

Abdelaziz, A.S. (2000). Airborne spectrometric studies and uranium mineralization in Um Bogma-Altor environs, southwestern Sinai, Egypt. Ph.D. Thesis, Dept. Geophysics, Fac. Sci., Ain Shams Univ., Egypt, 184.

Afifi, S.Y. (2001). Paragenesis of $\mathrm{Mn}-\mathrm{Cu}-\mathrm{U}$ in Quaternary paleochannels, West Central Sinai, Egypt. $5^{\text {th }}$ Int. Conf. Geochem. Alex. Univ., Egypt, 505-521.

Aita, S.K. (1996). Geological, mineralogical and geochemical studies on some radioactive anomalies of the Paleozoic sediments of Um Bogma area, west central Sinai, Egypt. M.Sc. Thesis, Fac. Sci., Cairo Univ., Egypt.

Al-Ibiary, M.G. (2000). Anomalous distribution of seismic intensities in the Nile delta, Egypt. Deltas, Modern and Ancient, Mansoura Univ., 209-217.

Amer, T.E. (1997). Geochemistry and extraction of uranium, copper and manganese from the ore materials of the uraniferous Paleozoic sedimentary rocks, West Central Sinai, Egypt. Ph.D. Thesis, Fac. Sci., Cairo Univ., Egypt, 139.

Ammar, F.A.; Abdou, N.M.F. and Dewedar, A.A. (1999). Mineralogy and Geochemistry of the Radioactive shale bed of the middle Member of Um Bogma Formation in Allouga Exploratory Tunnels, West central Sinai, Egypt. $4^{\text {th }}$ Int. Conf. Geochem., Alex. Univ., Egypt, 179-198.
Ashami, A.S. (1995). Studies on geology and uranium occurrences of some Paleozoic rocks, Wadi Allouga area, Sinai, Egypt. M.Sc. Thesis, Fac. Sci., Zagazig Univ., Egypt, 156.

Ashami, A.S. (2003). Structural and lithologic controls of uranium and copper mineralization in Um Bogma environs, southwestern Sinai, Egypt. Ph.D. Thesis, Geol. Dept., Fac. Sci., Mansoura Univ., Egypt, 134.

Arnous, M.O. (2000). Integrated remote sensing and GIS investigation of mineralizations in Saint Catherine area, South Sinai, Egypt. M.Sc. Thesis, Suez Canal Univ., Fac. Sci., Dept. Geol., Ismailia, Egypt., 125.

Arnous, M.O. (2004). Geo-environmental assessment of Cairo-Ismailia road area, Egypt, using remote sensing and geographic information system (GIS). Ph.D. Thesis, Geol. Dept., Fac. Sci., Suez Canal Univ., Ismailia, 283.

Arnous, M.O.; Aboulela, H.A. and Green, D.R. (2011). Geo-environmental hazards assessment of the north western Gulf of Suez, Egypt. J. Coast Conserv., 15 (1): 37 -50. doi:10.1007/s11852-0100118-z.

Be'eri-Shlevin, Y.; Katzir, Y. and Whitehouse, M. (2009). Postcollisional tectono-magmatic evolution in the northern Arabian- Nubian Shield (ANS): time constraints from ionprobe $\mathrm{U}-\mathrm{Pb}$ dating of zircon. J. Geol. Soc. (London), 166: 71-85.

Bishay, A.F. (1994). Geological investigation and physical benefits of xenotime sediments of Um Bogma Area, Sinai, Egypt. M.Sc. Thesis, Fac. Sci., Cairo Univ., Egypt, 188.

Botros, N. (1995). The effect of rift tectonics on the mode of distribution of uranium bearing-sediments, Um Bogma 
area, West Central Sinai. Egypt. Ascad Sci., 45: 193-204.

Diabat, A.A. (2011). Fracture systems of granites and Quaternary deposits of the area east of Aqaba: indicators of reactivation and neotectonic activity, Arab J. Geosci, 6(3): 679-695.

El-Aassy, I.E.; ElGaly, M.M.; Nada, A.A.; ElFeky, M.G.; Abd ElMaksoud, T.M.; Talaat, S.M. and Ibrahim, E.M. (2011). Effect of alteration processes on the distribution of radionuclides in uraniferous sedimentary rocks and their environmental impact, southwestern Sinai, Egypt. J. Radioanal. Nucl. Chem., 289: 173-184.

El-Aassy, I.E.; El-Moafy, A.A.; Hilmy, M.E. and Sallam, O.R. (2003). The control of uranium distribution in the Paleozoic sedimentary section of Um Bogma area, Southwestern Sinai, Egypt. Egypt. J. Geol., 47 (2): 1325-1339.

El-Kassas, I.A. (1967). Geologic and Radiometric Prospection of Radioactive Raw Materials in West Central Sinai. Int. Report, Dept. Geol. and Raw Materials (AEE), Cairo.

EIRakaiby, M.L. and El-Aassy, I.E. (1989). Structural interpretation of Paleozoic-Mesozoic rocks, southwestern Sinai, Egypt. Annal Geol. Surv. Egypt, XVI, 269-273.

ElShahat, A. and Kora, M. (1988). Composition of dolostones of Um Bogma Formation, Sinai. Mansoura Sci. Bulletin, Egypt, 15: 33-58.

EISharkawi, M.A.; El-Aref, M. and Abdel-Motelib A. (1990). Manganese deposits in a Carboniferous paleokarst profile, Um Bogma region, West Cent. Sinai, Egypt. Mineralium Deposita, 25: 343.

El-Agami, N.L. (1996). Geology and radioactivity studies on the Paleozoic rock units in the Sinai Peninsula, Egypt.
Ph.D. Thesis, Fac. Sci., Mansoura Univ., Mansoura, Egypt, 302.

El-Gezeery, M.V. and Marzouk, I.M., (1974). Miocene rock stratigraphy of Egypt. Egypt. J. Geol., 18: 1-59.

El-Ghawaby, M.A.; Hegazi, A.M. and Arnous, M.O. (2001). Photolineaments factor as an indicator for probable sites of mineralization in Saint Catherine area Egypt. The Geol. Soc. Egypt. Egypt. J. Geol., 45 (1A): 1-10.

El-Rayes, A. and Arnous, M.O. (2015). A novel approach in hydrogeochemical exploration for Uranium mineralization: an example from Westcentral Sinai, Egypt. ACTA Geol. Sinica, 89 (4): 1801- 1840.

El-Rayes, A.E.; Arnous, M.O. and Abouelela H. (2015). Hydrogeochemical exploration for geothermal resources in South Sinai, Egypt, Utilizing GIS and Remote Sensing. Arab. J. Geosci., 8 (8): 5631 - 5647. doi : 10.1007/s12517- 0141667-5.

El-Shamy, I.Z. (1983). On the hydrogeology of west Sinai. Egypt. J. Geol., 27(1-2): 93-105. ERDAS (ed.) (1982-2001): ERDAS Field Guide. Atlanta (ERDAS, Inc.).

Eyal, M.; Litvinovsky, B.; Jahn, B.M.; Zanvilevich, A. and Katzir, Y. (2010). Origin and evolution of post-collisional magmatism: Coeval Neoproterozoic calc-alkaline and alkaline suites of the Sinai Peninsula. Chem. Geol., 269 (3-4): 153-179.

Gupta, R.P. (1991). Remote Sensing Geology, $1^{\text {st }}$ Ed. Heidelberg: Springer, Berlin, 356.

Hardcastle, K.C. (1995). Photolineament Factor: A new computer-aided method for remotely sensing the degree to which bedrock is fractured. Photogrammetric Eng. and Remote Sensing, 61 (6): 739747. 
Hill, E.S. (1992). Elements of structure geology. Chapman and Hall Ltd. \& Science Paper Backs, 502.

Khalifa, I.H. and Arnous, M.O. (2012). Assessment of hazardous mine waste transport in west central Sinai, using remote sensing and GIS approaches: a case study of Um Bogma area, Egypt, Arab. J. Geosci., 5(3): 407-420.

Kulhanek, O.; Korrat, I. and El-Sayed, A. (1992a). Activity and general tectonic of Red Sea. E.G.S. Proc. $10^{\text {th }}$ Ann. Meet.

Kulhanek, O.; Korrat, I. and El-Sayed, A. (1992b). Connection between recent seismicities in the Red sea and Egypt. E.G.S. Proc. $10^{\text {th }}$ Ann. Meet.

Maamoun, M. and Ibrahim, E.M. (1978). Tectonic activity in Egypt as indicated by earthquakes. Bull. Helwen Inst. Astr. Geophys, 170.

Mansour, M.Gh. (1994). Sedimentology and radioactivity of Um Bogma Formation, west central Sinai, Egypt. M.Sc. Thesis, Fac. Sci., Suez Canal Univ., Ismailia, Egypt, 157.

Morsy, A.M.; El-Fawal, F.M.; EL-Aassy, I.E. and Mansour, M.Gh. (1995). Sedimentology of the Um Bogma Formation, west central Sinai. Proc. $4^{\text {th }}$ conf. Geol. Sinai Develop., Ismailia, Egypt, 121-139.

Mostafa, A.M. and Qari, M.Y. (1995). An exact technique of counting lineaments. Eng. Geol., 39: 5-16.
Moussa, H. (1989). Earthquake activities in Egypt and Adjacent region and its relation to geotectonic features in A.R. Egypt. M.Sc. Thesis., Fac. Sci. Mansoura Univ., 190.

Moustafa, A.M. (1987). Drap folding in the Baba-Sidri area, eastern side of the Suez rift, Egypt. J. Geol., 31: 13-24.

Said, R. (1962). The Geology of Egypt. Amsterdam and New York, Elsevier Publ. Co.

Shata, A.E. (2006). Role of epigenetic processes in the enrichment of mineralized dolostone of Um Bogma Formation, Southwestern Sinai. Sedimentol. Egypt, 14: 219-242.

Smith, K. (2001). Environmental hazards, assessing risk and reducing disasters, 3rd edn. Taylor and Francis Group, 353.

Soliman, M.S. (1975). Petrology of Carboniferous dolostone marine transgression over West Central Sinai, Egypt. $7^{\text {th }}$ Int. Cong. Straits. Geol. Carbnonif., C.R. Krefeld, 4: 53-265. Berlin, Springer Verlag, 340.

Riad, S.; Maamoun, M. and Simpson, D.W. (1993). Focal mechanisms of some recent earthquakes in the Gulf of Suez area and their tectonic implications Ann. Geol., Surv. Egypt, XIX: 487-500.

Zakir, F.A.; Qari, M.Y. and Mostafa, M.E. (1999). A new optimizing technique for preparing lineament density maps. Int. Remote Sensing, 20 (6): 1075-1085. 


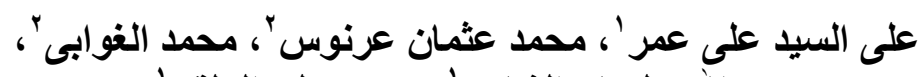

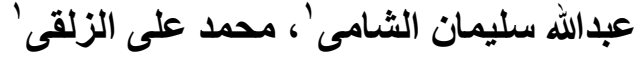

ا ـ قسم الجيولوجياو الاستشعار عن بُعد، هيئة المواد النووية، القاهرة، مصر.

Y ـ قسم الجيولوجيا، كلية العلوم، جامعة قناة السويس، مصر.

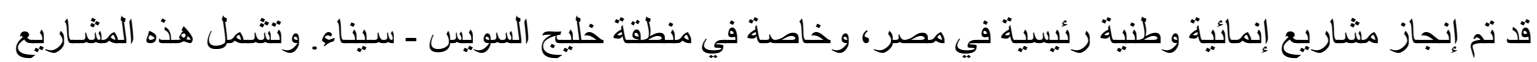

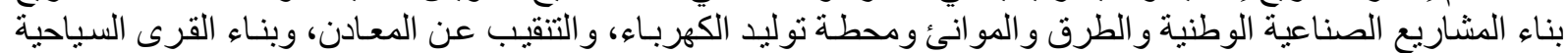

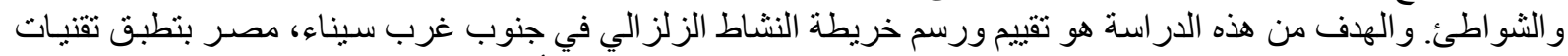

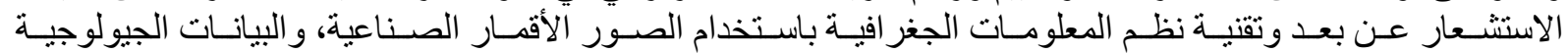
و الطوبو غر افية و البيانات الجيولوجية المئو المساعدة. و أظهر تكامل بيانات نظم المعلومات الجغر افيـة وتحليلها أن المنطقة مهددة

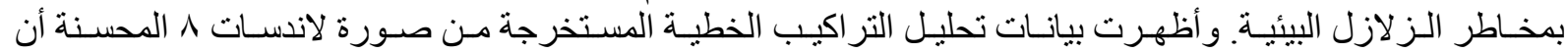

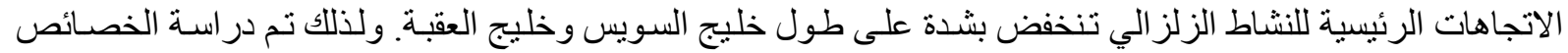

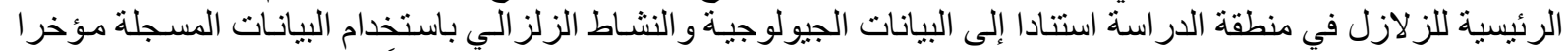

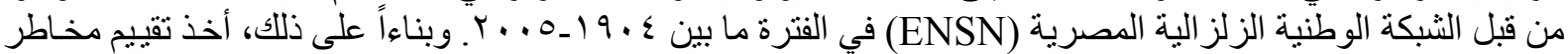

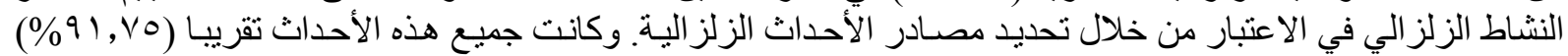

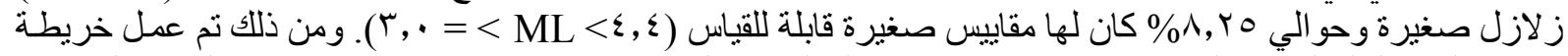

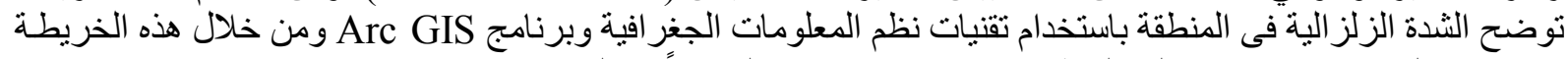
وجد ان هنالك تسعة اماكن احتمالية الخطر فيها بيتر اوح ما بين عالية جداً و وعالية. الكلمات الاسترشـادية: المخاطر الزلز الية، منطقة جنوب غرب سيناء، الاستشعار عن بُعد، نظم المعلومات الجغر افية. 